\title{
DIVERSITY OF ECTOMYCORRHIZAL FUNGI ASSOCIATED WITH QUERCUS PETRAEA IN THE NATIONAL PARK FRUŠKA GORA IN THE REPUBLIC OF SERBIA
}

\section{RAZNOLIKOST EKTOMIKORIZNIH GLJIVA NA HRASTU KITNJAKU (QUERCUS PETRAEA) U NACIONALNOM PARKU FRUŠKA GORA U REPUBLICI SRBIJI}

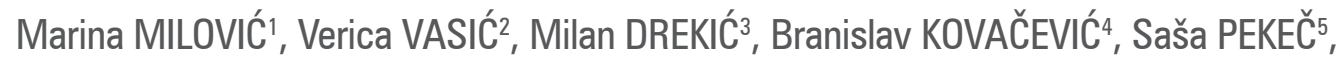 \\ Zoran GALIĆ, ${ }^{6}$ Saša ORLOVIĆ7
}

\begin{abstract}
SUMMARY
Although sessile oak is one of the most important deciduous forest tree species in Europe, data on the diversity of ectomycorrhizal (ECM) fungi on sessile oaks in the Republic of Serbia are scarce. The aim of this study was to provide the first insight into the diversity of ECM fungi on sessile oak in Serbia. Two sites Info center and Brankovac, located in National Park Fruška gora were chosen. ECM fungi were identified combining morphological and anatomical characterization with molecular analysis of nuclear rDNA internal transcribed spacer (ITS) region. All vital ECM root tips were counted, diversity indices were calculated, and ECM fungi were classified into the exploration types. The granulometric and chemical composition of soil were analyzed as well. At both sites, 26 different ECM fungal taxa were recorded in total, 17 taxa were observed at the site Info center and 12 taxa at Brankovac. ECM communities consisted of a few abundant taxa and a larger number of rare taxa. Lactarius quietus, Cenococcum geophilum, and Tomentella sublilacina were recorded at both sites. High abundance of contact and short-distance exploration types recorded in studied stands suggests that soils are sufficiently rich in total nitrogen and organic matter. Values of diversity indices recorded in studied sessile oak stands from Fruška gora were lower in comparison to those obtained in stands of different oak species across Europe which is likely induced by drought. To get a more thorough insight into the diversity of ECM fungi on sessile oak, research should be continued at more sites and seasonal dynamics should be included.
\end{abstract}

KEY WORDS: ectomycorrhiza, Quercus petraea, morpho-anatomical characterization, molecular identification, exploration types

\footnotetext{
1 dr Marina Milović, University of Novi Sad, Institute of Lowland Forestry and Environment, Antona Čehova 13, 21000 Novi Sad, Serbia, e-mail: katanicm@uns.ac.rs ${ }^{2}$ dr Verica Vasić, University of Novi Sad, Institute of Lowland Forestry and Environment, Antona Čehova 13, 21000 Novi Sad, Serbia, e-mail: vericav@uns.ac.rs ${ }^{3}$ dr Milan Drekić, University of Novi Sad, Institute of Lowland Forestry and Environment, Antona Čehova 13, 21000 Novi Sad, Serbia, e-mail: mdrekic@uns.ac.rs ${ }^{4}$ dr Branislav Kovačević, University of Novi Sad, Institute of Lowland Forestry and Environment, Antona Čehova 13, 21000 Novi Sad, Serbia, e-mail: branek@uns.ac.rs ${ }^{5}$ dr Saša Pekeč, University of Novi Sad, Institute of Lowland Forestry and Environment, Antona Čehova 13, 21000 Novi Sad, Serbia, e-mail: pekecs@uns.ac.rs ${ }^{6} \mathrm{dr}$ Zoran Galić, University of Novi Sad, Institute of Lowland Forestry and Environment, Antona Čehova 13, 21000 Novi Sad, Serbia, e-mail: galicz@uns.ac.rs ${ }^{7}$ prof. dr Saša Orlović, University of Novi Sad, Institute of Lowland Forestry and Environment, Antona Čehova 13, 21000 Novi Sad, Serbia, e-mail: sasao@uns.ac.rs
} 


\section{INTRODUCTION} UVOD

Sessile oak (Quercus petraea (Matt.) Liebl.), together with pedunculate oak (Q. robur $\mathrm{L}$.), is one of the most economically important deciduous forest tree species in Europe (Ducousso and Bordacs 2004, Eaton et al. 2016, Kesić et al., 2018). Their wood is of good quality and is valued for many purposes such as construction, as well as production of furniture and barrels. Also, oaks have an important ecological role because their acorns are a valuable food source for many animals. They are heliophilic, light-demanding trees which affect regeneration of many other tree species and enrich forest biodiversity. Although sessile oak prefers fertile and moist soils, it has a very large ecological niche and is quite tolerant of drought and poor soil (Ducousso and Bordacs 2004, Eaton et al. 2016). In the Republic of Serbia, the area under the forests of sessile oak occupies 173.200 ha and it makes up 7.9\% of the total forest area (Banković et al. 2008). This species is widespread in Serbia and appears from Fruška gora and Vršačke planine in the north to Kozjak, Kozarnik and Metohija in the south, and from Mount Tara in the west to Stara Planina in the east. It occurs in lowlands (outside floodplains), in hilly and lower mountainous areas, and spreads from $200 \mathrm{~m}$ a. s. 1., on the northern border of the area, to $1,200 \mathrm{~m}$ a. s. 1 ., on the southern and eastern border of distribution in Serbia (Stojanović et al. 2007).

In most temperate and boreal forest ecosystems, the establishment, growth and survival of trees depend on association with ectomycorrhizal (ECM) fungi. ECM fungi successfully take water and nutrients from the soil and translocate them to plants from which they receive photosynthetically produced carbohydrates in return (Smith and Read, 2008). Mycorrhizas are one of the essential components of the forest ecosystem stability. Particularly, they have stabilizing effects on forest trees that are under environmental stress. Common mycelial networks have an especially important role in forest regeneration, succession, and resistance against different stress factors (Selosse et al. 2006). Such networks connect plants of the same or different species and can affect the physiological and ecological processes of plants (Selosse et al. 2006). Also, mycorrhizal mycelium connects forest trees and ground vegetation with decomposers in forest soil, which affects the sustainability, productivity, and vitality of the forest (Kraigher 1996). Moreover, mycorrhizal fungi can improve plant tolerance to abiotic stress factors such as heat, drought, or presence of heavy metals, as well as increase resistance to pathogens and boost plant immunity (Smith and Read 2008, Smith et al. 2010, French 2017). The functional compatibility of the symbionts in ectomycorrhiza is species-specific and depends on both partners while stress tolerance and adaptation of individual ectomycorrhizae on different environmental conditions depend on species of ECM fungus and its morphological, physiological and ecological characters (Kraigher 1996). Therefore, information on the ECM community structure can provide valuable information about the physiology of forest trees and the functioning of forest ecosystems (Kraigher et al. 2011).

Classification of ectomycorrhizae based on the exploration types (ETs) connects morphology of ECM fungi, especially the amount and differentiation of emanating elements, with their ecology (Agerer 2001). Contact ET is represented by ectomycorrhizae with a smooth mantle and without rhizomorphs. Short-distance ET is characterized by a voluminous cover of emanating hyphae but without rhizomorphs. Medium-distance ET can be divided into three subtypes. In fringe subtype the fungi often form fans of emanating hyphae and rhizomorphs, smooth subtype has rather smooth mantles with only a few emanating hyphae, while mat-forming fungi have only a limited range of exploration. Longdistance ET is characterized by smooth ectomycorrhizae with few but highly differentiated rhizomorphs (Agerer 2001).

Since data on the diversity of ECM fungi on oaks in the Republic of Serbia are scarce, especially those studied underground, the aim of this study was to make the first insight into the diversity of ECM fungi on sessile oak in Serbia by choosing two sessile oak stands situated in National Park Fruška gora.

\section{MATERIALS AND METHODS MATERIJALI I METODE}

\section{Sampling site and procedures}

Sampling was conducted in two sessile oak (Quercus petrea (Matt.) Liebl.) stands situated on the ridge of the mountain Fruška gora, at sites near Info center (N 45 $09^{\prime} 14.9^{\prime \prime}$, E $19^{\circ}$ $50^{\prime} 40.2$ and $483 \mathrm{~m}$ a. s. 1.) and near viewpoint Brankovac (N $45^{\circ} 09^{\prime} 18.7^{\prime \prime}$, E $19^{\circ} 45^{\prime} 1.9$ and $471 \mathrm{~m}$ a. s. 1.). Other woody species present with a minor share were: Acer campestre L, Sambucus nigra L, Cornus sanguinea L, Fraxinus ornus L., Tilia argentea Desf. ex DC., and Rubus idaeus L at the site Info center; and Sambucus nigra L, Rubus idaeus L, Acer campestre L, and Tilia argentea Desf. ex DC at the site Brankovac.

Although Fruska gora spreads out in the zone with a moderate continental climate, the climate within the mountain area has subcontinental characteristics because of the change of the climatic characteristics along the height gradient and the forest cover. An exception is the climate of the mountain's ridges, with cold winters and chilly summers. The lowest mean value of air temperature occurs in January and amounts $-0.6^{\circ} \mathrm{C}$ and the highest mean in July with $21.4^{\circ} \mathrm{C}$, while the mean annual temperature is $11.2^{\circ} \mathrm{C}$. According to the average monthly sum of precipitation in this area, the months with the most precipitations are May and June, while the driest are September and October. (https://www. npfruskagora.co.rs/en/hidrology-and-climate/2. At the weather station Iriški venac for period 1965-1990 average pre- 
cipitation amount per season is as follows: winter $180 \mathrm{~mm}$, spring $198 \mathrm{~mm}$, summer $252 \mathrm{~mm}$, and autumn $161 \mathrm{~mm}$, the average amount of precipitation in the vegetative period is $443.6 \mathrm{~mm}$ and average annual amount of precipitation is $791.4 \mathrm{~mm}$ (Babić 2015).

Soil sampling was performed at the end of October 2017, in the absence of snow cover, and ten soil samples were taken per site. The sampling was performed with a standardized soil corer (Kraigher 1999) (4 cm in diameter and $18 \mathrm{~cm}$ in length, making a total sample volume of $274 \mathrm{~mL}$ ), 0.5-1 $\mathrm{m}$ from the target tree, as far as possible from nontarget trees. Soil samples were stored at $4^{\circ} \mathrm{C}$ for up to two months. Prior to analyses, each sample was submerged in cold tap water to loosen the soil structure. All roots were carefully washed from the soil. Using a dissecting microscope Olympus SZX 10 (Olympus Corp., Tokyo Japan) with magnifications 10-63× (light source: Olympus Highlight 3100 , daylight filter), all fine roots were separated as vital ECM root tips or as old, nonturgescent and unidentifiable. Vital ECM root tips were categorized into different morphotypes of ectomycorrhizae based on their morphological and anatomical characteristics. Later ones were assessed using a microscope (Olympus BX 53 ${ }^{\circ}$, Olympus Corp., Tokyo Japan) with magnifications 100-1000×. Morphotypes of ectomycorrhizae were described following the methodology given by Agerer (1991) and Kraigher (1996). If it was possible, a fungal partner was identified by comparison with published descriptions in Agerer et al. (2006), Agerer (2008), or Agerer and Rambold (2020).

Morphotypes of ectomycorrhizae were also classified into the ETs as proposed by Agerer (2001). All vital ECM root tips were counted. The granulometric and chemical composition of soil were analyzed as well.

\section{Molecular identification of ectomycorrhizal fungi}

Confirmation of fungal partners in ectomycorrhiza using molecular methods was based on PCR amplification of fungal nuclear rDNA internal transcribed spacer (ITS) region. Total genomic DNA was extracted from ECM root tips using a DNeasy ${ }^{\oplus}$ Plant Mini Kit (Qiagen, Hilden, Germany). If DNA extraction of representative root tips of some morphotype of ectomycorrhiza was not successful and morpho-an- atomical identification was insufficient to determine the ECM fungus, this ECM morphotype was labeled as an "unidentified" type. Amplifications were performed with ITS-1F (Gardes and Bruns 1993) and ITS 4 primer pair (White et al. 1990). The amplification reaction was performed in Eppendorf Master cycler (Eppendorf AG, Hamburg, Germany). Negative controls with no fungal DNA were run for each experiment to check for any contamination. The PCR mixture for one sample was composed of $2.5 \mu \mathrm{L}$ of $10 \times$ Gold Buffer, $2 \mu \mathrm{L}$ of deoxynucleotide triphosphates $(0.2 \mathrm{mM}$ each), $0.6 \mu \mathrm{L}$ of each primer (10 $\mu \mathrm{M}$ each), $2 \mu \mathrm{L}$ of $\mathrm{MgCl}_{2}(2.0 \mathrm{mM}), 15 \mu \mathrm{L}$ of sterile distilled water, $0.3 \mu \mathrm{L}$ of Taq polymerase $\left(5 \mathrm{U}^{-1}\right)$, and $2 \mu \mathrm{L}$ of a DNA extract. Thermal cycling conditions were as follows: initial denaturation and polymerase activation at $95^{\circ} \mathrm{C}$ for $5 \mathrm{~min} ; 13$ cycles at $94^{\circ} \mathrm{C}$ for $45 \mathrm{~s}, 55^{\circ} \mathrm{C}$ for $55 \mathrm{~s}$ and $72^{\circ} \mathrm{C}$ for $45 \mathrm{~s} . ; 13$ cycles at $94^{\circ} \mathrm{C}$ for $45 \mathrm{~s}, 55^{\circ} \mathrm{C}$ for $55 \mathrm{~s}$ and $72^{\circ} \mathrm{C}$ for $120 \mathrm{~s} ; 12$ cycles at $94^{\circ} \mathrm{C}$ for $45 \mathrm{~s}, 55^{\circ} \mathrm{C}$ for $55 \mathrm{~s}$ and $72^{\circ} \mathrm{C}$ for $180 \mathrm{~s}$ and a final extension at $72^{\circ} \mathrm{C}$ for $10 \mathrm{~min}$. Amplified DNA fragments were separated and purified from the agarose gel using the QIAquick gel extraction kit and QIAquick PCR purification kit (Qiagen, Valencia, CA, USA) and sent for sequencing in Macrogen Europe B.V. Species, genus, or family of ECM fungi were determined by comparing the sequences to those deposited in GenBank (NCBI 2020) and UNITE (Nilsson et al. 2018) database.

\section{Data analysis}

Diversity indexes were calculated per sample and per site (i. e. by pooling the ECM community data) following the formulas given by Atlas and Bartha (1981): (i) Species richness $(\mathrm{d})=(\mathrm{S}-1) / \log 10 \mathrm{~N}$, where $\mathrm{S}$ is the number of ECM fungal taxa and $\mathrm{N}$ is the number of all mycorrhizal tips; (ii) Shannon-Weaver's diversity index $(\mathrm{H})=\mathrm{C} / \mathrm{N}\left(\mathrm{N} \log \mathrm{N}-\boldsymbol{\Sigma} \mathbf{n}_{\mathrm{i}} \log n_{\mathrm{i}}\right)$, where $\mathrm{C}=2.3, \mathrm{~N}$ is the number of all mycorrhizal tips and $n_{i}$ is the number of mycorrhizal tips of an individual ECM fungal taxon.

\section{RESULTS}

\section{REZULTATI}

According to the granulometric and chemical composition of soil samples taken in studied sessile oak stands, soil on

Table 1. Granulometric and chemical composition of soil from sessile oak (Quercus petrea (Matt.) Liebl.) stands located at two sites in National Park Fruška gora

Tablica 1. Granulometrijski i kemijski sastav tla u sastojinama hrasta kitnjaka (Quercus petrea (Matt.) Liebl.) na dva lokaliteta u Nacionalnom parku Fruška gora

\begin{tabular}{|c|c|c|c|c|c|c|c|c|c|c|c|c|}
\hline \multirow[b]{2}{*}{ Site/Lokacija } & \multicolumn{7}{|c|}{ Granulometric composition/Granulometrijski sastav } & \multicolumn{5}{|c|}{ Chemical composition/Kemijski sastav } \\
\hline & $\begin{array}{c}\text { Coarse } \\
\text { sand (\%)/ } \\
\text { Krupni } \\
\text { pijesak } \\
(\%)\end{array}$ & $\begin{array}{l}\text { Fine sand } \\
(\%) / \\
\text { Sitan } \\
\text { pijesak } \\
(\%)\end{array}$ & $\begin{array}{l}\text { Silt (\%)/ } \\
\text { Prah (\%) }\end{array}$ & $\begin{array}{l}\text { Clay }(\%) / \\
\text { Glina (\%) }\end{array}$ & $\begin{array}{l}\text { Total } \\
\text { sand }(\%) / \\
\text { Ukupan } \\
\text { pijesak } \\
(\%)\end{array}$ & $\begin{array}{c}\text { Total } \\
\text { clay (\%)/ } \\
\text { Ukupna } \\
\text { glina (\%) }\end{array}$ & $\begin{array}{c}\text { Texture } \\
\text { class/ } \\
\text { Teksturna } \\
\text { klasa }\end{array}$ & $\mathrm{pH} / \mathrm{pH}$ & $\begin{array}{c}\text { Calcium } \\
\text { carbonate } \\
(\%) / \\
\text { Kalcijev } \\
\text { karbonat (\%) }\end{array}$ & $\begin{array}{c}\text { Humus } \\
(\%) / \\
\text { Humus } \\
(\%)\end{array}$ & $\begin{array}{c}\text { Nitrogen } \\
(\%) / \\
\text { Dušsik } \\
\text { (\%) }\end{array}$ & $\begin{array}{c}\text { Carbon } \\
(\%) / \\
\text { Uglfik } \\
(\%)\end{array}$ \\
\hline $\begin{array}{l}\text { Info center/ } \\
\text { Info centar }\end{array}$ & 10.9 & 37.7 & 38.5 & 12.9 & 48.6 & 51.4 & $\begin{array}{l}\text { loam/ } \\
\text { ilovača }\end{array}$ & 5.23 & 1.18 & 2.11 & 0.11 & 1.20 \\
\hline $\begin{array}{l}\text { Brankovac/ } \\
\text { Brankovac }\end{array}$ & 9.6 & 31.9 & 45.1 & 13.4 & 41.4 & 58.6 & $\begin{array}{l}\text { loam/ } \\
\text { ilovača }\end{array}$ & 5.46 & 1.75 & 2.52 & 0.13 & 1.41 \\
\hline
\end{tabular}


Table 2. Total and average values of the number of ectomycorrhizal fungal taxa, vital ectomycorrhizal root tips, and diversity indices in sessile oak (Quercus petrea (Matt.) Liebl.) stands located at two sites in National Park Fruška gora

Tablica 2. Ukupne i prosječne vrijednosti broja taksona ektomikoriznih gljiva, vitalnih ektomikoriznih korijenskih vrhova i indeksa raznolikosti u sastojinama hrasta kitnjaka (Quercus petrea (Matt.) Liebl.) smještenih na dva lokaliteta u Nacionalnom parku Fruška gora

\begin{tabular}{|c|c|c|c|c|}
\hline \multirow[t]{2}{*}{ Parameter/Parametar } & \multicolumn{2}{|c|}{ Info center/Info centar } & \multicolumn{2}{|c|}{ Brankovac/Brankovac } \\
\hline & $\begin{array}{c}\text { Total value } \\
\text { per site/Ukupna } \\
\text { vrijednost po lokaciji }\end{array}$ & $\begin{array}{l}\text { Average value per } \\
\text { sample/Prosječna } \\
\text { vrijednost po uzorku }\end{array}$ & $\begin{array}{c}\text { Total value per site/ } \\
\text { Ukupna vrijednost po } \\
\text { lokaciji }\end{array}$ & $\begin{array}{l}\text { Average value per } \\
\text { sample/Prosječna } \\
\text { vrijednost po uzorku }\end{array}$ \\
\hline $\begin{array}{l}\text { Number of ectomycorrhizal fungal taxa/ } \\
\text { Broj taksona ektomikoriznih gljiva }\end{array}$ & 17 & $2.8 \pm 0.6$ & 12 & $3.3 \pm 0.4$ \\
\hline $\begin{array}{l}\text { Number of vital ectomycorrhizal root tips/ } \\
\text { Broj vitalnih ektomikoriznih korijenskih vrhova }\end{array}$ & 1719 & $171.9 \pm 53.5$ & 1258 & $129 \pm 27.2$ \\
\hline Species richness index/Indeks bogatstva vrsta & 4.94 & $0.86 \pm 0.21$ & 3.54 & $1.10 \pm 0.21$ \\
\hline Shannon-Weaver index/Shannon-Weaver-ov indeks & 2.27 & $0.69 \pm 0.18$ & 2.09 & $0.87 \pm 0.13$ \\
\hline
\end{tabular}

both sites is acidic and belongs to textural class loam with high silt content (Table 1) suggesting relatively strong water absorption by soil particles and poor water availability for plants. On the other hand, soils in both stands belong to moderate humous soils and are well provided with nitrogen (Table 1).

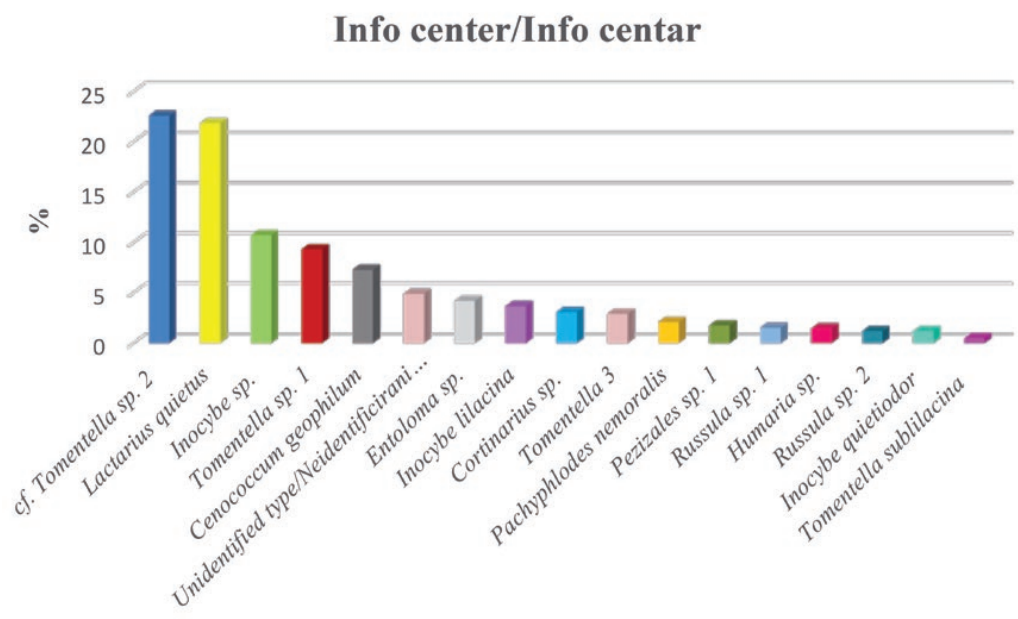

Ectomycorrhizal fungal taxa/Taksoni ektomikoriznih gljiva

Brankovac/Brankovac

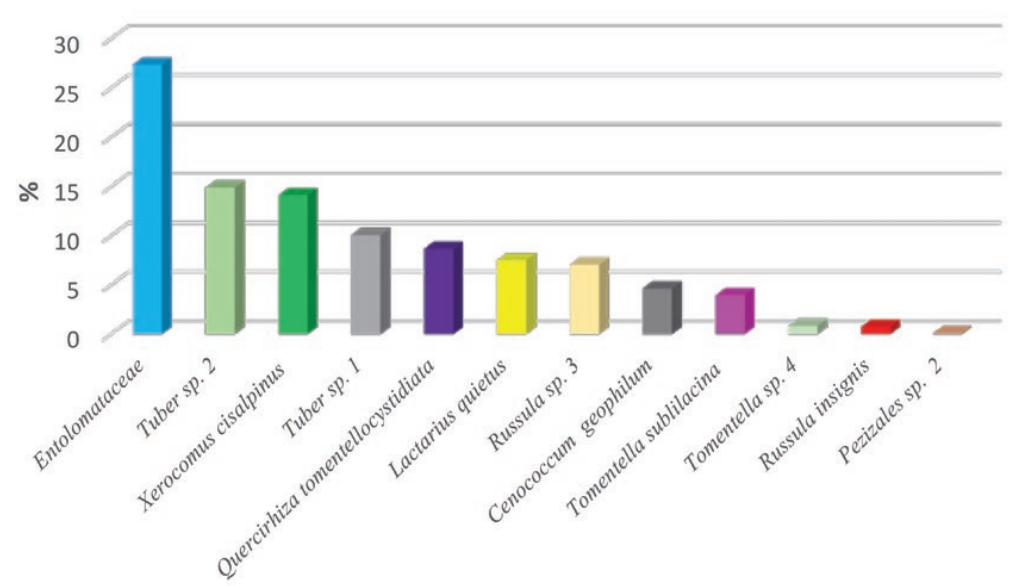

Ectomycorrhizal fungal taxa/Taksoni ektomikoriznih gljiva

Figure 1. Relative abundance of ectomycorrhizal fungal taxa (based on the number of ectomycorrhizal root tips belonging to the particular ectomycorrhizal fungal taxon in relation to all ectomycorrhizal root tips) in sessile oak stands from sites $\mathbf{A}$ Info center and $\mathbf{B}$ Brankovac

Slika 1. Relativna brojnost taksona ektomikoriznih gljiva (na temelju broja ektomikoriznih korijenskih vrhova koji pripadaju određenom taksonu ektomikoriznih gljiva u odnosu na sve ektomikorizne korijenske vrhove) u sastojinama hrasta kitnjaka sa lokaliteta A Info centar i B Brankovac 
Info center/Info centar

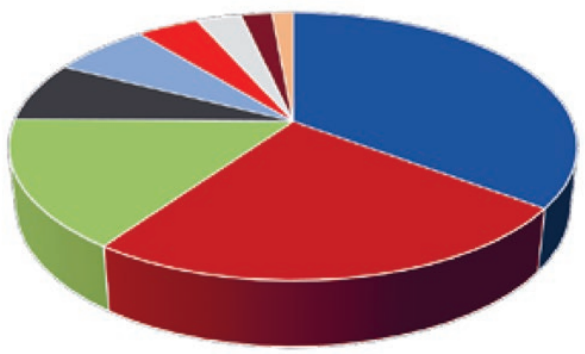

- Thelephoraceae

" Inocybaceae

- Unidentified family/Neidentificirana familija

Cortinariaceae

" Pyronemataceae

\section{Brankovac/Brankovac}

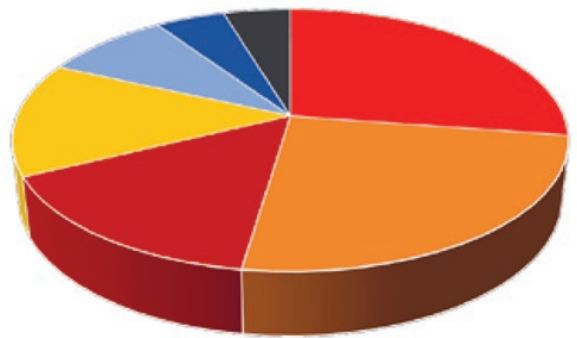

- Entolomataceae

- Russulaceae

- Tuberaceae

- Boletaceae

- Unidentified family/Neidentificirana familija

- Gloniaceae

Figure 2. Relative abundance of taxonomic families of ectomycorrhizal fungi based on the number of ectomycorrhizal root tips belonging to a particular family in relation to all ectomycorrhizal root tips in sessile oak stands from sites A Info center and B Brankovac

Slika 2. Relativna brojnost taksonomskih porodica ektomikoriznih gljiva na temelju broja ektomikoriznih korijenskih vrhova koji pripadaju određenoj porodici u odnosu na sve ektomikorizne korijenske vrhove u sastojinama hrasta kitnjaka sa lokaliteta A Info centar i B Brankovac

The total number of ECM fungal taxa recorded at the site Info center was somewhat higher than the one recorded at the site Brankovac (Tab. 2, Supplement Tab. 1). At both sites, a similar number of ECM fungal taxa was recorded per soil sample. The total number of vital ECM root tips counted in the sessile oak stand at Info center was almost $50 \%$ higher than at Brankovac. Although the total number of recorded ECM fungal taxa was higher at the site Info center, the average number of ECM fungal taxa and values of diversity indices calculated per soil sample were higher at the site Brankovac (Tab. 2).

In soil samples taken in sessile oak stands at sites Info center and Brankovac, 26 ECM fungal taxa were recorded in total (Fig. 1). Nine ECM fungi were identified to a species level, 13 to a genus level, one to a family level, two to an order level, and one ECM fungus remained unidentified. Among all observed ECM fungi only Tomentella sublilacina, Lactarius quietus and Cenococcum geophilum were recorded at both sites. At the site Brankovac, the most abundant ECM fungi were cf. Tomentella sp. 2 and Lactarius quietus with relative abundance higher than $20 \%$, then Inocybe sp. which made association with $10 \%$ of all root tips. At the site Brankovac dominating ECM fungus, identified as Entolomataceae sp., was associated with almost $30 \%$ of all ECM root tips, while Tuber sp. 2 and Xerocomus cisalpinus had relative abundance higher than $10 \%$. At both sites three most abundant ECM fungi associated with more than 50\% of all ECM roots (Fig. 1).

At the site Info center dominant fungal taxonomic families were Thelephoraceae, Russulaceae, and Inocybaceae which together encompassed more than $75 \%$ of all vital ECM root tips (Fig. 2A). Moreover, these three families were the most species-rich families at this site (Fig. 3A). On the other hand, at site Brankovac the most abundant families were Entolomataceae, Tuberaceae, Russulaceae, and Boletaceae and their individual relative abundances were above $10 \%$ (Fig. 2B). However, family Russulace was the most speciesrich at this site followed by Tuberaceae and Thelephoraceae (Fig. 3B). At both sites, ECM fungi belonging to the phylum Basidiomycota dominated the ECM community. ECM fungi belonging to Ascomycota were more abundant at the site Brankovac in comparison with Info center (data not shown).

At the site Info center short distance ET dominated, followed by contact ET and medium-distance ET, while long-distance ETs were not found at all. On the other hand, at the site Brankovac the most abundant was contact ET followed by short-distance ET and medium- distance ET, while long-distance ET was the least abundant (Tab. 3).

Table 3. Relative abundance ( \pm standard error) (\%) of ectomycorrhizal exploration types in sesile oak (Quercus petrea (Matt.) Liebl.) stands located at two sites in National Park Fruška gora

Tablica 3. Relativna brojnost ( \pm standardna pogreška) (\%) ektomikoriznih eksploracijskih tipova u sastojinama hrasta kitnjaka (Quercus petrea (Matt.) Liebl.) smještenih na dva lokaliteta u Nacionalnom parku Fruška gora

\begin{tabular}{lcc}
\hline $\begin{array}{l}\text { Exploration type/ } \\
\text { Eksploracijski tip }\end{array}$ & $\begin{array}{c}\text { Info center/ } \\
\text { Info centar }\end{array}$ & $\begin{array}{c}\text { Brankovac/ } \\
\text { Brankovac }\end{array}$ \\
\hline $\begin{array}{l}\text { Contact/Kontaktni } \\
\text { Short-distance/Kratkih udaljenosti } \\
\text { Medium-distance smooth/ }\end{array}$ & $53.8 \pm 11.8$ & $43.3 \pm 9$ \\
$\begin{array}{l}\text { Srednjih udaljenosti glatki } \\
\text { Medium-distance fringe/ }\end{array}$ & $9 \pm 9$ & $23.9 \pm 8.4$ \\
$\begin{array}{l}\text { Srednjih udaljenosti sa resama } \\
\text { Long-distance/Dugih udaljenosti }\end{array}$ & $6.2 \pm 4.6$ & 0 \\
\hline
\end{tabular}




\section{Info center/Info centar}

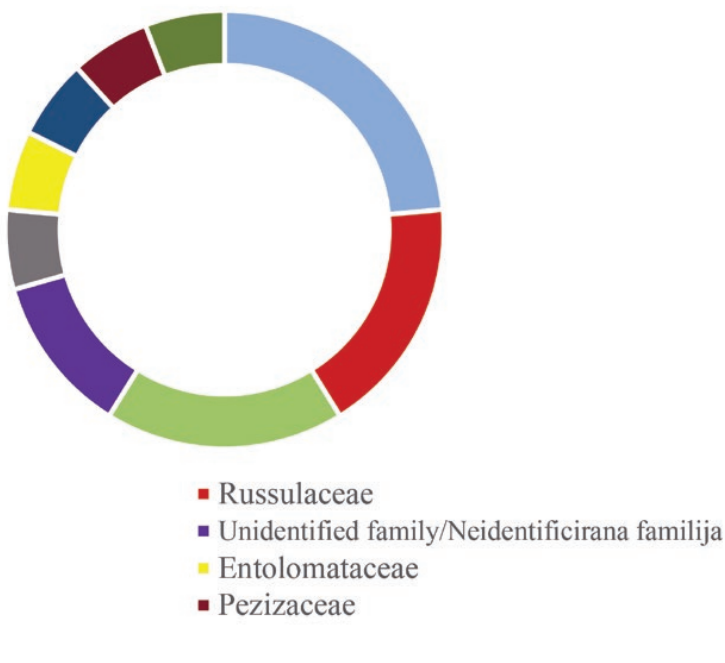

\section{Brankovac/Brankovac}

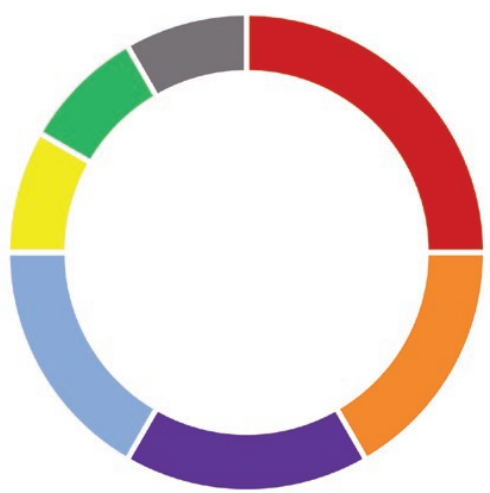

- Russulaceae

- Unidentified family/Neidentificirana familija

- Entolomataceae

- Gloniaceae
- Tuberaceae

- Thelephoraceae

- Boletaceae

Figure 3. Species richness of taxonomic families of ectomycorrhizal fungi based on the number of ectomycorrhizal taxa belonging to a particular family in relation to all ectomycorrhizal taxa in sessile oak stands from sites A Info center and B Brankovac

Slika 3. Bogatstvo vrsta taksonomskih porodica ektomikoriznih gljiva na temelju broja ektomikoriznih taksona koji pripadaju određenoj porodici u odnosu na sve ektomikorizne taksone u sastojinama hrasta kitnjaka sa lokaliteta A Info centar i B Brankovac

\section{DISCUSSION}

\section{RASPRAVA}

In two sessile oak stands in National Park Fruška gora studied in autumn, 26 different ECM fungal taxa were recorded in total, of which 14 taxa were observed only at the site Info center, nine taxa only at the site Brankovac and three ECM fungal taxa on both sites. However, an analysis of ectomycorrhizas across nine European countries at long-term and intensively monitored oak plots, showed that the average richness was 55, ranging from 24 fungal taxa in the Netherlands to 83 in Romania (Suz et al. 2014). In a temperate oak forest in northeast France, 75 fungal symbionts were recorded in 15 months (Courty et al. 2008). In two stands of Q. robur and Q. petrea in Austria, 46 and 38 ECM morphotypes were differentiated within 3 years (Kovacs et al. 2000). The number of ECM fungi recorded in our study was considerably lower in comparison to these studies. Differences in the obtained number of ECM taxa could be due to the lower number of soil samples taken in our study and the fact that sampling was done only in one season. Abundant species are prone to be present all year long, some species occur only in a particular season or month, while some ECM fungi are present all year long but with fluctuating abundance (Courty et al. 2008). On the other hand, species 
richness recorded in our research was similar to the one obtained in three declining pedunculate oak stands in western Poland where a total of 18 ECM fungal species was revealed and ECM fungal species richness ranged from 11 to 15 taxa (Bzdyk et al. 2019). Also, in the forest of the Taurus mountains in Central Germany, 18 different ECM genera and species were determined on sessile oak (Schirkonyer et al. 2013), while in Ireland 21 ECM taxa were found on native oaks Q. petrea and Q robur (O'Hanlon and Harrington, 2012).

On average, three ECM fungi were recorded in soil samples from sites Info center and Brankovac. This is considerably lower in comparison to oak stands in Austria where eight morphotypes were found averagely (Kovacz et al. 2000) and in the forest of $Q$. ilex in Spain where on average seven species were recorded (de Roman and de Miguel, 2005). Shannon-Weaver index per soil sample at sites Info center and Brankovac with values 0.7 and 0.9 , respectively, is considerably lower compared to the ones recorded in oaks stands in Austria where vital trees had Shannon-Weaver index 1.3-1.5 (Kovacz et al. 2000) and in the Q. ilex forest in Spain where this index was 1.2 in the burned stand and 1.3 in the control stand (de Roman and de Miguel 2005). However, if we compare total values of Shannon-Weaver index calculated for sites Info center and Brankovac (2.3 and 2.1, respectively) with the ones obtained by Kovacz et al. (2000) in Austria for aggregated soil samples taken under vital trees (in the range 2.6-2.7) we can conclude that these values are comparable.

The low average number of ECM fungal taxa and value of Species richness and Shannon-Weaver index per soil sample could be explained by the lack of precipitation, which is characteristic for the studied sites during September and October, when sampling was conducted. Also, the summer season in 2017 was one of the warmest for the period 2010-2017 (Galić et al. 2018). Drought caused dying out of a large number of roots and consequently high number of old, non-turgescent, and nonmycorrhizal roots were observed in soil samples (data not shown), while the number of ECM fungal taxa per soil sample was decreased. Bzdyk et al. (2019) suggest that the number of vital and non-vital ECM roots is influenced by short-term factors such as local droughts, but these factors do not influence total ECM diversity which is supposed to be more susceptible to long-term trends.

At both sites, ECM community was made up of a few abundant taxa and a larger number of rare taxa. This is in accordance with numerous studies (Courty et al. 2008, O'Hanlon and Harrington 2012, Suz et al. 2014, Rosinger et al. 2018, Bzdyk et al. 2019). It is assumed that a large number of taxa present at low frequencies may constitute biological insurance for adaptation to changing environmental conditions. Namely, a more diverse ECM community that includes rare ECM species is important in case if ecological conditions change, as some dominant ECM fungi might not be adapted to the new conditions (Penna et al.2010, O'Hanlon and Harrington 2012).

Ectomycorrhizal fungi determined as Lactarius quietus, Cenococcum geophilum, and Tomentella sublilacina were recorded at both studied sites from Fruška gora. Similarly, the most abundant ECM fungi on temperate oaks across nine European countries were Lactarius quietus, Cenococcum geophilum, and Russula ochroleuca (Suz et al. 2014). Moreover, in a temperate oak forest Lactarius quietus, Tomentella sublilacina, Cenococcum geophilum, and Russula sp.1 were abundant and present all year long (Courty et al. 2008). Lactarius quietus is an oak specialist which was recorded as one of the most abundant and frequently occurring ECM fungi on temperate oaks across Europe (Voříšková et al. 2013, Bzdyk et al. 2019). Cenococcum geophilum is a species complex that is the most widely distributed making symbiosis with over 200 tree hosts (LoBuglio 1999). C. geophilum is also known for its ability to withstand extreme conditions, especially drought, but it is frequently found on oaks across Europe (de Roman and Miguel 2005, Schirkonyer et al. 2013).

Families Russulaceae, Cortinariaceae and Thelephoraceae were reported to be dominant in temperate and Mediterranean oak forests (Courty et al. 2008, Richard et al. 2011). Moreover, research of ectomycorrhizae in temperate oak forests across Europe revealed that the most abundant family was Russulaceae, followed by Gloniaceae, Thelephoraceae, and Cortinariaceae (Suz et al. 2014). A higher number of ECM fungal taxa belonging to the phylum Basidiomycota in comparison to Ascomycota obtained in our study is concordant to many previous studies (Richard et al. 2011, Suz et al. 2014; Bzdyk et al. 2019 etc.)

Classification of ectomycorrhizae based on ETs connects ECM fungal morphology with their ecology (Agerer 2001). Each exploration type has different functional traits and different capabilities to take up and translocate nutrients and to store carbon (Hobbie and Agerer 2010). Furthermore, it was proven that ETs have site indication value, particularly in relation to nutrients availability and soil composition $(\mathrm{Ru}-$ dawska et al. 2011).

At both sites on the mountain Fruška gora, contact and short-distance ETs dominated. According to Bzdyk et al. (2019), the contact ET is considered well adapted to soil layers rich in organic matter and to relatively nutrient-rich conditions. In contrast, ETs with abundant mycelial biomass, such as the long-distance ET, were found to be well adapted to nutrient-poor conditions, especially poor in nitrogen $(\mathrm{N})$ (Hobbie and Agerer 2010). Usually, mycorrhizae with contact, short- and medium-distance smooth ETs seem to use labile, mainly inorganic $\mathrm{N}$, while medium distance fringe and mat, and long-distance ETs are believed to use organic $\mathrm{N}$ and have degradation enzymes with the strongest potential activities (Lilleskova et al. 2011, Suz et al. 2014). 
Mean annual temperature, $\mathrm{pH}$, and tree species significantly influenced the distribution of the different ETs on root tips of beech, spruce and pine stands across Europe (Rosinger et al. 2018). Contact or short-distance ETs of ECM fungi had mostly broad environmental ranges. In contrast, longdistance ETs of ECM fungi were particularly restricted to sites with high mean annual temperatures and low precipitation. Shorter distance ETs are favored in colder climates where soils were richer in total $\mathrm{N}$ and plant carbon loss is smaller. On the other hand, long-distance ETs of ECM fungi that dominated communities in warmer and less fertile environments are more carbon demanding (Rosinger et al. 2018, Defrenne et al. 2019). A high abundance of contact and short-distance ETs recorded in analysed stands on Fruška gora suggests that these soils are sufficiently rich in total nitrogen and organic matter which is concordant with the measured content of humus and nitrogen in the soils.

A potential positive role of ECM functional diversity is indicated by finding the highest diversity of ETs in stands with the best tree health status (Bzdyk et al. 2019). Furthermore, a high diversity of ETs can make communities more resilient to environmental change (Suz et al. 2014). Thus, it is important to conserve the diversity of ECM fungi and also the diversity of their ETs in our forests.

\section{CONCLUSIONS ZAKLJUČCI}

This work presents results of the first study of the diversity of ECM fungi on sessile oak in Serbia. In two sessile oak stands situated in National Park Fruška gora, 26 ECM fungal taxa were described and identified mostly with molecular methods. Fourteen taxa were observed only at the site Info center, nine taxa only at the site Brankovac while Lactarius quietus, Cenococcum geophilum, and Tomentella sublilacina were recorded at both sites. Contact and short-distance exploration types dominated in studied stands suggesting that soils are sufficiently provided with total nitrogen and organic matter. Lower values of diversity indices in sessile oak stands from Fruška gora in comparison to different oak species across Europe can be explained by drought which lasted during the summer at studied sites. In order to get a more thorough insight into the diversity of ECM fungi on sessile oak in Serbia, research should be continued at more sites and seasonal dynamics should be included as well.

\section{ACKNOWLEDGEMENT ZAHVALA}

The study was realized within the project "Bioecological studies of sessile oak for the purpose of sustainable forest management in the National Park "Fruška gora" financed by the Republic of Serbia, Autonomous Province of Vojvodina, Provincial Secretariat for Higher Education and Scientific Research and the project 451-03-9/2021-14/ 200197 financed by the Ministry of Education, Science and Technological Development of the Republic of Serbia

\section{REFERENCES LITERATURA}

- Agerer, R., R.M., Danielson, S., Egli, K., Ingleby, D., Luoma, R., Treu, 2006: Descriptions of ectomycorrhizae $10^{\text {th }}$ ed., EinhornVerlag, Schwäbisch Gmünd

- Agerer, R., G., Rambold, 2020: DEEMY - An Information System for Characterization and Determination of Ectomycorrhizae, www.deemy.de

- Agerer, R., 1991: Characterisation of ectomycorrhiza, Techniques for the study of mycorrhiza, In: Norris, J.R., D.J., Read, A.K., Varma (Eds). Methods in Microbiology 23, Academic Press, 25-72, London

- Agerer, R., 2008: Colour Atlas of Ectomycorrhizae. $13^{\text {th }}$ ed., Einhorn-Verlag, Schwäbisch Gmünd

- Agerer, R., 2001: Exploration types of ectomycorrhizae. A proposal to classify ECM mycelial systems according to their patterns of differentiation and putative ecological importance, Mycorrhiza, 11: 107-114.

- Atlas, R., R., Bartha, 1981: Introduction to microbiology. Addison-Wesley Publishing Company, 242-244, Reading

- Babić, V., 2015: Klimatske katakteristike Fruške Gore. Šumarstvo 67(4):25-38. [in Serbian with English summary]

- Banković, S., M., Medarević, D., Pantić, N., Petrović, 2009: Nacionalna inventura šuma Republike Srbije - šumski fond Republike Srbije. Ministarstvo poljoprivrede šumarstva i vodoprivrede Republike Srbje - Uprava za šume, Beograd

- Bzdyk, R.M., J., Olchowik, M., Studnicki, J.A., Nowakowska, T., Oszako, A., Urban, D., Hilszczańska, 2019: Ectomycorrhizal Colonisation in Declining Oak Stands on the Krotoszyn Plateau, Poland. Forests, 10(30): 1-21.

- Courty, P.E., A., Frank, J.C., Pierrat, J., Garbaye, 2008: Temporal changes in the ectomycorrhizal community in two soil horizons of a temperate oak forest. Appl Environ Microbiol, 74(18): 57925801.

- De Roman, M., A.M., De Miguel, 2005: Post-fire, seasonal and annual dynamics of the ectomycorrhizal community in a Quercus ilex L. forest over a 3-year period. Mycorrhiza, 15: 471-482.

- Defrenne, C.E., T.J., Philpott, S.H.A., Guichon, W.J., Roach, B.J., Pickles, S.W., Simard, 2019: Shifts in ectomycorrhizal fungal communities and exploration types relate to the environment and fine-root traits across interior douglas-fir forests of Western Canada. Front Plant Sci, 10:643.

- Ducousso, A., S., Bordacs, 2004: EUFORGEN Technical Guidelines for genetic conservation and use for pedunculate and sessile oaks (Quercus robur and Q. petraea). International Plant Genetic Resources Institute, Rome, Italy, 6 p.

- Eaton, E., G., Caudullo, S., Oliveira, D., de Rigo, 2016: Quercus robur and Quercus petraea in Europe: distribution, habitat, usage and threats. In: San-Miguel-Ayanz, J, D., de Rigo, G., Caudullo, T., Houston Durrant, A., Mauri (Eds) European Atlas of Forest Tree Species. Publ. Off. EU, 160-163, Luxembourg 
- Engelmann, H.D., 1978: Zur Dominanzklassifizierung von Bodenarthropoden. Pedobiologia, 18:378-380. [in German]

- French, K.E., 2017: Engineering mycorrhizal symbioses to alter plant metabolism and improve crop health, Front. Microbiol, 8: 1403.

- Galić Z., M., Drekić, V., Vasić, S., Pekeč, L., Kesić, Z. Novčić, 2018: Monitoring temperaturnih uslova u šumskim ekosistemima na nivou II praćenja prekograničnog zagađenja u delu Republike Srbije - AP Vojvodini. Topola/Poplar, 201/202: 15-32. [in Serbian with English summary]

- Gardes M., T.D., Bruns, 1993: ITS primers with enhanced specificity for basidiomycetes-application to the identification of mycorrhizae and rusts. Mol Ecol, 2: 113-118.

- Hobbie, E.A., R., Agerer, 2010: Nitrogen isotopes in ectomycorrhizal sporocarps correspond to belowground exploration types. Plant Soil, 327: 71-83.

- Kesić, L, S., Stojnić, S., Orlović, L., Pavlović, R., Lozjanin, A., Tepavac, E., Vaštag, 2018: Varijabilnost morfoloških karaktera žira hrasta lužnjaka (Quercus robur L.), kitnjaka (Q. petraea (Matt.) Lieb.) i cera (Q. cerris L.) Topola/Poplar, 201/202:187201. [in Serbian with English summary]

- Kovacs, G., M., Pausch, A., Urban, 2000: Diversity of ectomycorrhizal morphotypes and oak decline. Phyton (Horn, Austria), 40(4): 109-116.

- Kraigher, H., S., Al Sayegh-Petkovšek, 2011: Mycobioindication of stress in forest ecosystems. In: Rai, M., A., Varma (Eds). Diversity and biotechnology of ectomycorrhizae vol 25, Soil Biology, Springer, 301-322, Berlin, Heidelberg

- Kraigher, H., 1999: Diversity of types of ectomycorrhizae on Norway spruce in Slovenia. Phyton, 39(3): 199-202.

- Kraigher, H., 1996: Tipi mikorize: taksonomija, pomen, aplikacija. Zbornik gozdarstva in lesarstva. 49: 33-66 [In Slovenian with English summary]

- Lilleskova, E.A., E.A., Hobbie, T.R., Horton, 2011: Conservation of ectomycorrhizal fungi: exploring the linkages between functional and taxonomic responses to anthropogenic $\mathrm{N}$ deposition. Fungal ecol, 4: 174 -183.

- LoBuglio, K.F., 1999: Cenococcum. In: Ectomycorrhizal fungi key genera in Profile. Springer, 287-309, Berlin, Heidelberg

- National Park Fruška gora, 2020: Hidrology \& Climate, Available: https://www.npfruskagora.co.rs/en/hidrology-and-climate/

- NCBI GenBank, 2020; Accessed: http://www.ncbi.nlm.nih.gov/ genbank/index.html.

- Nilsson, R.H., K.-H., Larsson, A.F.S., Taylor, J., BengtssonPalme, T.S., Jeppesen, D., Schigel, P., Kennedy, K., Picard, F.O., Glöckner, L., Tedersoo, I., Saar, U., Kõljalg, K., Abarenkov, 2018: The UNITE database for molecular identification of fungi: handling dark taxa and parallel taxonomic classifications. Nucleic Acids Res, 47: 259-264.
- O’Hanlon, R., T. J., Harrington, 2012: Similar taxonomic richness but different communities of ectomycorrhizas in native forests and non-native plantation forests. Mycorrhiza, 22(5): 371-82.

- Pena, R., C., Offermann, J., Simon, P.S., Naumann, A., Geßler, J., Holst, H., Mayer, I., KögelKnabner, H., Rennenberg, A., Polle A., 2010: Girdling affects ectomycorrhizal diversity and reveals functional differences of EM community composition in a mature beech forest (Fagus sylvatica). Appl Environ Microbiol., 76: 1831-1841.

- Richard, F., M., Roy, O., Shahin et al., 2011: Ectomycorrhizal communities in a Mediterranean forest ecosystem dominated by Quercus ilex: seasonal dynamics and response to drought in the surface organic horizon. Ann. For. Sci., 68: 57-68.

- Rosinger, C., H., Sandén, B., Matthews, M., Mayer, D.L., Godbold, 2018: Patterns in ectomycorrhizal diversity, community composition, and exploration types in european beech, pine, and spruce forests. Forests, 445, https://doi.org/10.3390/ f9080445

- Rudawska, M., T., Leski, M., Stasińska, 2011: Species and functional diversity of ectomycorrhizal fungal communities on Scots pine (Pinus sylvestris L.) trees on three different sites. Ann forest sci, 68: 5-15.

- Schirkonyer, U., C., Bauer, G., Rothe, 2013: Ectomycorrhizal diversity at five different tree species in forests of the Taunus Mountains in Central Germany. Open J. Ecol., 03(01):66-81

- Selosse, M-A, F., Richard, X., He, S.W., Simard, 2006: Mycorrhizal networks: les liaisons dangeureuses?, Trends Ecol. Evol., 21: 621-628.

- Smith, S.E., E. Facelli, S. Pope, F.A. Smith, 2010: Plant performance in stressful environments: interpreting new and established knowledge of the roles of arbuscular mycorrhizas, Plant Soil 326: 3-20.

- Smith, S.E., D.J. Read, 2008: Mycorrhizal symbiosis, Third edition, ElsevierAcademic Press, 787p., London

- Stojanović, Lj., V. Isajev, D., Karadžić, M., Krstić, V., Bajić, M. Medarević, B., et al., 2007: Hrast kitnjak (Quercus petraea agg. Ehrendorfer 1967) u Srbiji. Stojanović, Lj. (Ed), Beograd: Udruženje šumarskih inženjera i tehničara Srbije, Šumarski fakultet, Univerzitet u Beogradu, Beograd[ in Serbian]

- Suz, L.M., N., Barsoum, S., Benham, et al., 2014: Environmental drivers of ectomycorrhizal communities in Europe's temperate oak forests. Mol. Ecol., 23(22):5628-5644.

- Voříšková, J., V., Brabcová, T., Cajthaml, P., Baldrian, 2014: Seasonal dynamics of fungal communities in a temperate oak forest soil. New Phytol., 201(1): 269-78.

- White, T.J., T., Bruns, S., Lee, J., Taylor, 1990: Amplification and direct sequencing of fungal ribosomal RNA genes for phylogenetics. In: Innis, M.A., D.H., Gelfand, J.J., Sninsky, T.J., White (Eds.) PCR Protocols. A Guide to Methods and Applications, Academic Press, 315-322, San Diego

\section{SAŽETAK}

Hrast kitnjak je jedna od ekonomski i ekološki najvažnijih vrsta listopadnog šumskog drveća u Europi. U većini ekosustava umjerene klimatske zone zasnivanje, rast i preživljavanje stabala ovise o njihovoj zajednici sa ektomikoriznim (ECM) gljivama. Pri tome informacije o strukturi ECM zajednice mogu pružiti dragocjene informacije o funkcioniranju šumskih ekosustava. Međutim, podaci o razno- 
likosti ECM gljiva na hrastovima u Republici Srbiji su rijetki. Cilj ovog istraživanja bio je pružiti prvi uvid u raznolikost ECM gljiva na hrastu kitnjaku u Srbiji. Odabrane su dvije lokacije Info centar i Brankovac, smještene u Nacionalnom parku Fruška gora. ECM gljive su identificirane kombiniranjem morfološke i anatomske karakterizacije s molekularnom analizom nuklearne rDNA ITS regije. Prebrojani su svi vitalni ECM korijenski vrhovi, izračunati indeksi raznolikosti i ECM gljive su klasificirane u eksploracijske tipove. Analiziran je i granulometrijski i kemijski sastav tla. Na obje lokacije zabilježeno je ukupno 26 taksona ECM gljiva, 17 taksona zabilježeno je na lokaciji Info centar i 12 taksona na Brankovcu. ECM zajednice sastojale su se od nekoliko brojnih ECM gljiva i većeg broja rijetkih ECM gljiva. Na obje lokacije zabilježeni su Lactarius quietus, Cenococcum geophilum i Tomentella sublilacina. Na lokaciji Info centar dominirale su porodice Thelephoraceae, Russulaceae i Inocybaceae, dok su na lokaciji Brankovac najzastupljenije familije bile Entolomataceae, Tuberaceae i Russulaceae. Velika brojnost kontaktnih i eksploracijskih tipova kratkih udaljenosti zabilježena u proučavanim sastojinama sugerira da su tla dovoljno bogata ukupnim dušikom i organskim tvarima. Vrijednosti indeksa raznolikosti zabilježene u proučavanim sastojinama hrasta kitnjaka s Fruške gore bile su niže u usporedbi s onima dobivenim u sastojinama različitih vrsta hrasta diljem Europe, što je vjerojatno uzrokovano sušom. Da bi se dobio temeljitiji uvid u raznolikost tipova ektomikoriza na hrastu kitnjaku, trebalo bi nastaviti s istraživanjima na više mjesta i uključiti sezonsku dinamiku.

KLJUČNE RIJEČI: ektomikoriza, Quercus petraea, morfo-anatomska karakterizacija, molekularna identifikacija, eksploracijski tipovi 